\title{
Determinants of Bank Efficiency: Conventional versus Islamic
}

\author{
Nabilah Rozzani ${ }^{1}$ \& Rashidah Abdul Rahman ${ }^{1}$ \\ ${ }^{1}$ Accounting Research Institute, Universiti Teknologi MARA, Shah Alam, Malaysia \\ Correspondence: Nabilah Rozzani, Accounting Research Institute, Universiti Teknologi MARA, 40450 Shah \\ Alam, Selangor, Malaysia. E-mail: nabilah.rozzani@gmail.com
}

Received: May 7, 2013 Accepted: June 5, 2013 Online Published: June 18, 2013

doi:10.5539/ijbm.v8n14p98 URL: http://dx.doi.org/10.5539/ijbm.v8n14p98

\begin{abstract}
This study explores the area of bank efficiency with the usage of Stochastic Frontier Analysis. The main objective is to identify determinants affecting conventional and Islamic banks' efficiency, focusing towards banks in Malaysia. Year-end financial data was obtained from a sample of 19 conventional banks and 16 Islamic banks that operate in Malaysia, where these banks' annual reports from the years 2008 until 2011 were referred for the purpose of analysis. An overall view of the results indicates that the levels of profit efficiency for both conventional and Islamic banks in Malaysia were highly similar. Further, it could be observed that efficiency would be better for conventional banks with the increment of bank size and also the decrement of both operational cost and credit risk, while the efficiency for Islamic banks would be better with only the decrement of operational cost.
\end{abstract}

Keywords: efficiency, stochastic frontier analysis, conventional and Islamic banks

\section{Introduction}

\subsection{Introduction and Research Objectives}

The recent financial crisis has led to a large increase in the number of bank failures, making the banking industry more complicated than other industries despite the financial details that banks file in their annual reports $(\mathrm{Ng} \&$ Rusticus, 2012). The issue of bank survival in this millennium has attracted a high interest to scholars of financial services and regulators, as the diversity of significance for bank survival does not only apply to strategic decisions made by banks, but also to decisions made by regulators that are concerned of bank stability (Berger \& Bouwman, 2013). Regulatory and technology advancement factors was said to have contributed to this threat, that includes the removal of regulatory ceilings on bank deposit rates, introduction of interest bearing checking accounts, relaxation of branching laws, the increasing competition with the emergence of mega banks through mergers and acquisitions, and also the lack of personal interaction between bankers, borrowers and depositors (Ndu \& Wetmore, 2005). Hence, in periods of crisis, many financial institutions are bound to face hardship for business survival (Pramuka, 2011).

Efficiency has been constantly said to be the leading cause of bank failure (Barr, Seiford \& Siems, 1994). In simple accounting terms efficiency refers to the capability of company in their usage of assets, which is measured relatively to how a specific amount of asset would generate revenue using accounting-based financial ratio (Wild, Shaw \& Chiappetta, 2009). To banking regulators, a precise and on-going measuring of bank's performance would allow allocation of resources to be more effective, assist in audits targeting, leading to a better understanding on the operation of banks (Barr et al., 1994). The Central Bank of Malaysia had concluded in 2001 that the performance of Islamic banks' operation is still relatively insignificant in comparison to conventional banking, even though their performance has been encouraging these years. Hence, it has been recommended for the Islamic banking sector to focus on improving their level of efficiency (Central Bank of Malaysia, 2001) so that they are able to shine in the banking industry and compete effectively while staying true to its roots.

In today's globalized industry, it is important for all companies, including financial institutions, to stay in the business. In Malaysia especially, various banks have merged and businesses being shut down by insolvency and financial distress, due to the 1997-1998 Asian Economic Crisis (Mat-Nor, Mohd Said \& Hisham, 2006). For example, Bank Bumiputera Malaysia Berhad had merged with Bank of Commerce Berhad in 1999 to form Bumiputera Commerce, that later changed its name to CIMB Bank Berhad (CIMB Group, 2011). This shows 
how close bank operation relates to a country's economic condition. Further, according to Mat-Nor et al. (2006); efficiency is one of the many factors that had made the economic changes unavoidable. Therefore, it is important for banks to remain competitive to survive in the long run. Banks should also be able to function efficiently to ensure it contributes to the nation's overall economic growth. As such, there is a need to review the efficiency level of financial institutions, in Malaysia.

Previous studies involving the measurement of efficiency are descriptive in nature (e.g. Lang \& Welzel, 1996; Saaid, Rosly, Ibrahim, \& Abdullah, 2003; Hassan, Mohamad \& Bader; 2009). Comparisons were only made from the observation of bank structure and also by estimated level of efficiency. Studies that do examine factor affecting performance, such as Hassan (2005), do not provide in-depth clarification on how variables were used and if there were any restrictions to the variables being used in study. Hence, this provides the need for a study that could relate the measurements of efficiency with appropriate determinants to observe their interaction in similar economic environment. By that, this study aims to explore the difference of bank's efficiency between conventional and Islamic banks, also exploring determinants affecting both types of banks in the Malaysian banking environment. The determinants identified from previous literature include bank size, operational cost and credit risk.

By displaying the potential of interaction between both Islamic and conventional banks in Malaysian banking system, this study is hoped to provide useful information for stakeholders to make better investment decisions and to help both conventional and Islamic banks to mark and re-evaluate their performance based on their level of efficiency. Also, this study hopes to provide relevant views on how determinants of efficiency could consequently lead to bankruptcy in banks due to competition of institutions. By that, both conventional and Islamic banks operating in Malaysia are able to assess their performance and efficiency as well as identifying the areas that they could focus on in improving the said performance and efficiency.

This paper is further structured to be as follows. Section 2 develops the theory and hypotheses being tested. The research method is defined in Section 3 with results reported in Section 4. The discussion of the findings and the conclusions are drawn are in Section 5.

\subsection{Literature Review and Hypothesis Development}

Malaysia is growing in the sense of their respective Islamic banking sector; where a study by Alwyni (2011) had shown that since the last five years, the growth in Islamic banking in Malaysia is rapid and higher, as being compared to the overall growth of the country's banking industry. This study had shown that the average growth rate of Islamic banking in Malaysia is 19 percent per annum, compared to the banking industry's 11 percent growth. Therefore, following the aspirations of the Central Bank of Malaysia's Financial Sector Plan (Central Bank of Malaysia, 2001) to make Malaysia a global centre for Islamic financial services, there is a need to observe the performance and efficiency of Islamic banks in order to oversee the development of Islamic banking sector, thus providing a gap to previous studies.

According to Bashir (2001), the evaluation of efficiency and its determinants are essentially important due to the fast growing environment in today's economic structure. This globalisation has indeed put Islamic banks in strong competition with conventional banks in financial markets. This is added to the situation where some countries had made complete transformation of their banking system, with the addition to the Islamic elements to this system. Hence, there is a need to determine which among the many potential determinants of efficiency that would emerge to be most important.

From previous literature, this study had identified that size of banks; operational cost and credit risk are the determinants that affect bank efficiency. This is where bank size has a positive relationship, while operational cost and credit risk having negative relationships towards the banks' efficiency levels.

\subsubsection{Bank Size}

Based from the theory of Conventional Economic Efficiency, it was argued that size promotes efficiency by reducing possible costs of gathering and processing information (Bashir, 1999; QFinance, 2010; Said, 2012). Large banks are capable to mobilize more funds in generating high returns for its depositors and equity holders due to its diversification, which is achieved from having more resources. By these resources, larger banks are able to finance large numbers of profitable investment opportunities and acquire better access to investment activities.

Major studies found a positive relationship between bank size and efficiency (e.g. Yudistira, 2004; Hassan, 2005; Rossi, Schwaiger \& Winkler, 2005; Delis \& Papanikolaou, 2009; Srairi, 2010; Siddiqui \& Shoaib, 2011). As a general rule, larger firms tend to have higher level of efficiency. However, there is a limitation in this 
relationship between bank size and efficiency (Delis \& Papanikolaou, 2009). One of them is that banks should be studied within a specific bank group to have positive relationship to level of efficiency (Girardone, Molyneux \& Gardener, 2004). There will be numerous effects to different types of banks. Berger, Hunter \& Timme (1993) and also Miller \& Noulas (1996) reviewed that wider penetration of market and increase in profit at less cost by large banks, hence better efficiency; while Rossi et al. (2005) added another reason that larger banks would have better efficiency to control its cost better. On the other side, the effect of size could be negative for banks that are extremely large due to bureaucracy (Nigmonov, 2010). This caused some studies (Fuentes \& Vergara, 2003; El Moussawi \& Obeid, 2011) to find negative relationship between bank sizes with efficiency. El Moussawi \& Obeid (2011) argued that the relationship between the size and the efficiency of Islamic banks does not mean that large banks have attained their optimal size, where a proportion of their productive inefficiency is probably resulted from an inadequate size measure.

Based on the Conventional Economics Efficiency theory and findings of previous researchers, it is hypothesized that larger banks would acquire better efficiency, since these banks would have more resources to be allocated for better services to its customers. This brings the formulation of the first hypothesis as follows.

H1: There is a significant positive relationship between the size of banks and bank's efficiency.

H1a: There is a significant positive relationship between size of conventional banks and its efficiency.

$\mathrm{H} 1 \mathrm{~b}$ : There is a significant positive relationship between size of Islamic banks and its efficiency.

\subsubsection{Operational Cost}

According to the Conventional Economic Efficiency theory, banks may obtain cost reductions from the decrement in per-unit costs that resulted from the increment of size or scale of a bank's operations (Gjirja, 2003). This hence leads to the expansion of these banks through horizontal acquisition and increment of efficiency (Yudistira, 2004).

According to Srairi (2010), operation cost is negatively related to efficiency. This is supported by Cebenoyan \& Strahan (2004), who had argued that the ability in managing productive operations is better on banks that engage in greater amounts of lending. Having greater amounts of lending would later lead to the lowering of production costs, consequently enabling banks to operate more effectively. The study of Chen (2009) had also argued that higher income from sources such as fees and commissions could anticipate for higher operational cost in order for the banks to provide such services. Therefore, banks that incur more operational costs would be less efficient due to the high risk that would be taken up by the increment of cost. This hence develops the second hypothesis as below.

$\mathrm{H} 2$ : There is a significant negative relationship between operational cost and banks' efficiency.

H2a: There is a significant negative relationship between operational cost and conventional banks' efficiency.

$\mathrm{H} 2 \mathrm{~b}$ : There is a significant negative relationship between operational cost and Islamic banks' efficiency.

\subsubsection{Credit Risk}

From the theory of Conventional Economic Efficiency, it was argued that the primary justification for regulating risks is to maximise economic efficiency (Schwarcz, 2008). Economic incentives are done to overdrafts, consequently reducing direct credit risk in order to increase efficiency (Board of Governors of the Federal Reserve System, 2005).

According to Chen (2009), credit risk is another determinant that might considerably change a bank's efficiency scores when it operates in similar risk level and business areas as other banks. To Ariff \& Can (2008), higher credit risk is incurred by banks with higher ratio of loan to total asset. As these banks would have higher non-performing loans, they are less efficient. Banks which provide more loans are also expected to be more efficient in profit as they take more risks. Study by El Moussawi \& Obeid (2011) had concluded that there is a negative relationship observed between risk and efficiency of Islamic banks due to the fall of economic activity, which is often followed by a rise of bankruptcy probability. This would then bring effect to the bank's profit, hence increasing the number of non-performing loans. In contrast, studies by Fuentes \& Vergara (2003), Hassan (2005) and Srairi (2010) had found that credit risk has a significantly positive relationship with both performance and efficiency, with an indication that the banks' output mix is favourable to promote efficiency. By that, banks that have a higher number of non-performing loans would be taking more risks and become more efficient. This discussion brings to the third hypothesis as follows.

H3: There is a significant negative relationship between credit risk and bank's efficiency. 
H3a: There is a significant negative relationship between credit risk and conventional banks' efficiency.

H3b: There is a significant negative relationship between credit risk and Islamic banks' efficiency.

\subsubsection{Conceptual Framework}

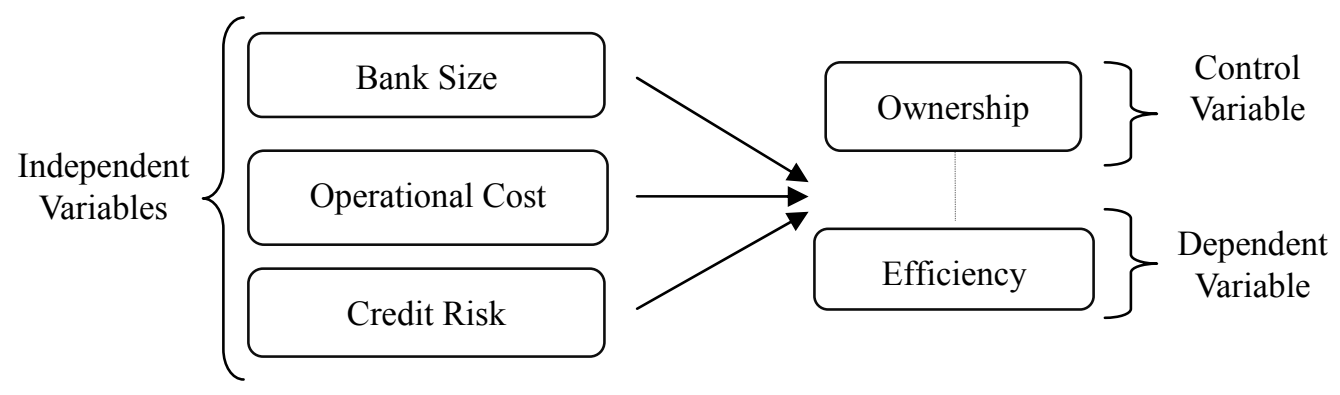

Figure 1. Conceptual framework

As shown in Figure 1, this study examines the determinants of efficiency. The dependent variable of the purpose of this study is efficiency, while the independent variables are bank size, operational cost and also credit risk. This study also incorporates a dummy variable as control, which is type of ownership.

The Conventional Economic Efficiency theory argues that companies are able to achieve their output at the lowest possible cost for every unit being produced (Said, 2012). Further, overall performance and efficiency can be accomplished only when there are no other patterns of resources utilization that are able to deliver an enhanced overall outcome. Hence, with the increment of bank size and decrement of both operational cost and credit risk, a high level of allocated performance and efficiency is achievable. The objective of increasing bank size would then trigger to mergers and acquisition, in order to achieve operating and financial synergy, subsequently increasing performance and efficiency (Sufian, Abdul Majid \& Haron, 2008). Operating synergy is produced from cost reductions that occur as a result of Economies of Scale. This means that every decrement of costs would derive from the increment in size or scale of a firm. Plus, this theory provides an argument that more efficient and performing banks would have lower costs and earn greater market share. This theory is further enhanced by the fact that lower efficiency in managing assets would lead to higher credit risk being endured by the organization (Ahmad \& Ahmad, 2004). Hence, this characteristic would be further induced by the growing number of banks being established in recent years, that would provide for competition among these banks to emerge as being the best that there is. By having competitive environments, a more concentrated and efficient banking systems could be achieved (Demirgüç-Kunt, Laeven \& Levine, 2004).

In this study, the factor of ownership was also introduced as a control variable due to differences found in data, which is domestic and foreign-owned banks in the sample collected.

\section{Methodology}

A sample consisting of Islamic and conventional banks operating in Malaysia was selected for this study. As obtained in the Central Bank of Malaysia's List of Licensed Banking Institutions in Malaysia, there are 27 conventional banks (Central Bank of Malaysia, 2012a) as well as 16 Islamic banks (Central Bank of Malaysia, 2012b) being established in Malaysia as at 31st December 2011. However, the study had excluded 8 conventional banks, which annual reports were not published for some of the years chosen for analysis. This included three banks that were recently established in 2012, which are India International Bank (Malaysia) Berhad, Mizuho Corporate Bank (Malaysia) Berhad and National Bank of Abu Dhabi Malaysia Berhad. The final sample collected of these banks is 19 conventional banks as well as 16 Islamic banks. This is to meet the objective of this study, which is exploring the efficiency level of conventional and Islamic banks in Malaysia. Finally, after taking into consideration the four years of observation (2008-2011), a set of 140 data was derived for analysis.

\subsection{Independent Variables}

The variable SIZE represented bank size, measured using the natural logarithm of Total Assets as a proxy. This is consistent to the studies of Bashir (1999); Milbourn, Boot \& Thakor (1999); Gjirja (2003); Hassan (2005); Rossi et al. (2005); Altunbas, Carbo, Gardener \& Molyneux (2007); and El Moussawi \& Obeid (2011). 
The variable OPRC represented operation cost incurred by these banks in their operation. The indicator for operation cost was measured as a ratio of Cost by Income. This is similar to the studies of Hughes \& Mester (2009); Chen (2009); Fiordelisi, Marques-Ibanez \& Molyneux (2011); and Srairi (2010).

The variable CRED represented credit risk, being measured using the natural logarithm of Non-Performing Loans as proxy. This is consistent to the studies of Kwan \& Eisenbeis (1997); Barajas, Steiner \& Salazar (1999); Fuentes \& Vergara (2003); and Das \& Ghosh (2009).

\subsection{Dependent Variable - Profit Efficiency Estimates}

The methodology of Stochastic Frontier Analysis employs financial measurements, in terms of sums and ratios, as a building base in estimating profit efficiency. The financial measurement being used for the purpose of this study, following the studies of Srairi (2010) are reflected as in Table 1. After measuring these input and output ratios, the derived data would be inserted in software FRONTIER 4.1 for the calculation of profit efficiency estimates using Stochastic Frontier Analysis. The outcome from this analysis would display the percentage of profit efficiency for each bank being analysed.

Table 1. Summary of ratios

\begin{tabular}{ccc}
\hline Methodology & Component & Proxy \\
\hline & & Price of Labour \\
Stochastic Frontier Analysis & & Price of Fund \\
& & Price of Physical Capital \\
& Output & Total Loans \\
& & Total of Other Earnings Assets \\
\hline
\end{tabular}

Source: Srairi (2010)

The input and output parameters chosen are consistent with the research made by Srairi (2010), being summarised in Table 1. This study adopts an intermediation approach to define the three input variables and two output variables as a parametric measure of efficiency level. As was mentioned in Srairi (2010), the appropriateness of this approach comes when the sample banks operates as an independent entity (Bos \& Kool, 2006). Using this method, banks act as intermediaries that receive funding and use labour and capital to turn the funding received into loans and other earning assets. Berger \& Humphrey (1997) said that this approach is more powerful as most of banks' expenses are interest-related. This is particularly true in the case of commercial banks, but still at the same time, applicable to Islamic banks as well. Hence, the input variables include Price of Labour, Price of Fund and Price of Physical Capital. To measure Price of Labour, this study follows Altunbas et al. (2007) in using the ratio of Personnel Expenses, being divided to Total Assets as proxy. Price of Fund is measured by dividing Interest Expenses Paid to Total Deposits. However, since Islamic banks are based on non-interest banking activities, this study represents Interest Expenses as Profits Distributed to Depositors. Price of Physical Capital is measured using the sum of Other Administrative Expenses and Other Operating Expenses, being divided by Fixed Assets. For the output component, Total Loans is measured by the total of loans provided to customer by banks, while Other Earning Assets is measured by the sum of inter-bank funds, investment securities and other investments. Investment securities in this context include treasury bills, government bonds and other securities.

The dependent variable used in this study is the profit efficiency estimates which were obtained from the analysis of Stochastic Frontier Analysis. The application of profit efficiency estimates as a dependent variable is consistent to the studies of Lang \& Welzel (1996); Saaid et al. (2003); Hassan (2005); Mohamad, Hassan \& Bader (2008); Ismail \& Zainal Abidin (2009); and Srairi (2010).

\subsection{Control Variables}

This study had employed the usage of a control variable OWNR, which represents ownership of banks. This control variable is measured by dummy variable, where 1 represented local bank while 0 represented foreign bank. The usage of this control variable is in line with past literature of Lu, Yang, Hsiao, \& Lin (2007); Cadet (2008); and Thangavelu \& Findlay (2010). 


\section{Data Analysis and Results}

The data in this study were analysed using Stochastic Frontier Analysis for the measurement of bank efficiency through the estimation of profit efficiency and Multiple Linear Regression for examining the relationship of determinants with bank efficiency. The results will be presented in two sections, based from the foundation of these methodologies.

\subsection{Profit Efficiency Estimates}

Table 2. Descriptive analysis for banks' profit efficiency estimates (2008-2011)

\begin{tabular}{cccccc}
\hline & Mean & Standard Deviation & Minimum & Maximum & Sig. \\
\hline Conventional Banks & $46.01 \%$ & $27.23 \%$ & $0.34 \%$ & $99.90 \%$ & \multirow{2}{*}{0.645} \\
Islamic Banks & $43.88 \%$ & $27.04 \%$ & $1.80 \%$ & $94.35 \%$ & \\
Overall & $45.03 \%$ & $27.02 \%$ & $0.34 \%$ & $99.90 \%$ & $0.000^{*}$ \\
\hline
\end{tabular}

* Value is significant at $1 \%$ level

As seen in Table 2, the overall statistical results indicate that average profit efficiency during the years 2008 until 2011 is 45.03 percent for all 35 banks being examined. This indicates that the overall efficiency of banks in Malaysia is still below 50 percent of optimum efficiency. The results show that Malaysian banks are still slacking in utilizing its resources, in terms of deposits and capital, efficiently to produce similar service at a lower cost (Hassan et al., 2009). This could be caused by the aspiration of these banks to provide services with better quality for their customers, leading these banks to incur higher costs (Kraft \& Tirtiroğlu, 1998). These high cost could include banks expanding its operations by setting up new branches (Saaid et al., 2003). It raises concern that if the situation continues, the over-utilisation of capital to the less profitable branches could lead to the banks not paying their demand deposits on time, as they have insufficient reserve. Further, looking at the mean of profit efficiency estimates for both conventional and Islamic banks, it is evident that the group of conventional bank achieves a higher estimate of profit efficiency. However, by the two sample t-test, the difference of means between conventional bank and Islamic banks are not significant, thus showing that the levels of these banks profit efficiency are highly similar. Mohamad et al. (2008) found that conventional banks in Africa obtained a higher profit efficiency estimate than Islamic banks. The study of Hassan (2005) also found that the conventional banking industry is relatively more efficient compared to their Islamic counterparts in a worldwide perspective. Baten \& Kamil (2010) also found that the efficiency estimates for conventional banks are higher than Islamic banks in Bangladesh. The slight disadvantage towards Islamic banks could be caused by the lack of expertise in Islamic banks and also due to the limitation in the sense of product variation being offered by these banks (Kamaruddin, Safa \& Mohd, 2008).

Table 3. Mean analysis for banks' profit efficiency estimates for individual years

\begin{tabular}{ccccc}
\hline & $\mathbf{2 0 0 8}$ & $\mathbf{2 0 0 9}$ & $\mathbf{2 0 1 0}$ & $\mathbf{2 0 1 1}$ \\
\hline Conventional Banks & $38.29 \%$ & $47.94 \%$ & $51.45 \%$ & $46.22 \%$ \\
Islamic Banks & $35.01 \%$ & $45.63 \%$ & $52.17 \%$ & $42.70 \%$ \\
Overall & $36.86 \%$ & $46.88 \%$ & $51.78 \%$ & $44.61 \%$ \\
\hline
\end{tabular}

Looking at the four years of analysis, as in Table 3, it is evident that the profit efficiency for all 35 banks increase in 2009 and 2010, but drops in 2011. The banks collectively reach the 50 percent of optimum efficiency only in 2010. The remaining years show these banks to be below the 50 percent mark. This was possibly caused by the lack of bank management ability to better control the usage of their internal resources in times when profit maximisation was influenced by uncontrollable external factors such as competition, regulations, and Gross Domestic Product (Hassan et al., 2009).

\subsection{Multiple Linear Regression}

The relationship between identified determinants with efficiency estimates that has been measured through Stochastic Frontier Analysis would be further analysed by regression. Two models are developed, where one is to suit the data from conventional banks, while the other is for data of Islamic banks. The regression model that 
would be used is as Equation 1.

$$
\text { RATE }=\beta_{0}+\beta_{1} \text { SIZE }+\beta_{2} \text { OPRC }+\beta_{3} C R E D+\beta_{4} \text { OWNR }
$$

where

$$
\begin{array}{ll}
\text { RATE } & =\text { Profit Efficiency Estimates } \\
S I Z E & =\text { Bank Size } \\
\text { OPRC } & =\text { Operation Cost } \\
C R E D & =\text { Credit Risk } \\
\text { OWNR } & =\text { Ownership } \\
\beta_{0} & =\text { Constant coefficient for the regression model } \\
\beta_{1} & =\text { Coefficient for bank size } \\
\beta_{2} & =\text { Coefficient for operation cost } \\
\beta_{3} & =\text { Coefficient for credit risk } \\
\beta_{4} & =\text { Coefficient for ownership }
\end{array}
$$

3.2.1 Determinants of Efficiency

Table 4. Multiple linear regression analysis: determinants of efficiency (conventional and Islamic)

\begin{tabular}{ccccccc}
\hline \multirow{2}{*}{ Model } & \multicolumn{3}{c}{ Conventional } & \multicolumn{3}{c}{ Islamic } \\
\cline { 2 - 7 } & Coefficient & t-value & p-value & Coefficient & t-value & p-value \\
\hline CONSTANT & -152.301 & -3.999 & $0.000^{*}$ & -93.830 & -1.119 & 0.268 \\
BANK SIZE & 13.745 & 4.781 & $0.000^{*}$ & 7.841 & 1.249 & 0.217 \\
OPERATIONAL COST & -0.191 & -3.217 & $0.002^{*}$ & -0.062 & -2.279 & $0.026^{* *}$ \\
CREDIT RISK & -2.829 & -1.897 & $0.062^{* * *}$ & 0.391 & 0.158 & 0.875 \\
OWNERSHIP & 1.502 & 0.213 & 0.832 & 10.300 & 1.225 & 0.226 \\
\hline $\mathbf{R}^{2}$ & & 0.382 & & & 0.210 & \\
Adjusted R & & 0.348 & & & 0.156 & \\
F-Statistics & & 10.992 & & & 0.007 & \\
p-value & & 0.000 & & & 64 & \\
Durbin-Watson & & 2.323 & & & & \\
N & & 76 & & &
\end{tabular}

* Value is significant at $1 \%$ level

$* *$ Value is significant at $5 \%$ level

$* * *$ Value is significant at $10 \%$ level

Table 4 summarised the result from Multiple Linear Regression analysis of the second model for both conventional and Islamic banks; that examined the determinants of efficiency. Based from the 0.382 and 0.210 value of $\mathrm{R}^{2}$ respectively for conventional and Islamic banks, the statistical results showed that 38.2 percent and 21 percent of the changes in profit efficiency estimated of these groups of bank were explained by the variation of bank size, operational cost and credit risk.

Further, the adjusted $\mathrm{R}^{2}$ value of 0.348 and 0.156 showed that on an adjusted basis, the independent variables in both conventional and Islamic models were collectively 34.8 percent and 15.6 percent related to bank's efficiency. The 10.992 and 3.915 value of $F$ statistics showed a significant linear relationship between all independent variables and efficiency for both conventional and Islamic models. The 2.323 and 1.920 values of Durbin-Watson obtained from analysis, on the other hand, showed data independence between the independent variables to bank efficiency for both models built for conventional and Islamic banks. This indicated that all the independent variables were not correlated to one another; that might have otherwise influenced the outcome 
from the analysis.

With reference to Table 4, it could be seen that for the conventional bank model, bank size had a significantly positive relationship with bank efficiency, while both operational cost and credit risk had significantly negative relationships with efficiency. The relatively better efficiency in larger banks could be due to the smaller difference with respect to capital size and its history (Hassan et al., 2009). This thus followed the theory of Conventional Economic Efficiency, whereby with the increment of bank size, firms were able to produce output at lower costs and subsequently increase the firm's overall performance and efficiency. To add to that, the relative cost of managing credit risks is reduced when the risk is better diversified (Hughes \& Mester, 2011). Meanwhile, for the Islamic bank model, bank size and credit risk was found not to have significant relationship with bank efficiency, while operational cost had a significantly negative relationship with efficiency. This could be caused by the stiff competition between the small Islamic banking industries, leading to these banks taking greater risks that require additional costs to be incurred (Kwan \& Eisenbeis, 1997; Hassan et al., 2009). This is true in the case of Islamic banks in Malaysia, where most of these banks are similar in size and they take similar risks in order to compete with one another. Further, it could be seen that for the conventional bank model, bank size marked the highest influence towards bank efficiency, followed by credit risk and operational cost.

It can also be observed from Table 4 that the relationship of ownership was not significant for both conventional and Islamic bank models. Other than that, the significant contradictory difference found in both conventional and Islamic bank models thus supported the findings of the main model that type of bank did not have a significant relationship towards bank efficiency.

\section{Summary and Conclusions}

This study had explored the area of bank efficiency, where it is important for these banks to have better efficiency in terms of the usage of its profit in providing better services. Emphasize was put on the comparison of conventional and Islamic banks, since both classifications of banks are slowly growing in line with Malaysia's status as a developing country. Hence, the main objective of the study was to identify determinants affecting bank efficiency, provided in comparison between conventional and Islamic banks.

From the analysis of Stochastic Frontier Analysis, it could be deduced that the levels of profit efficiency achieved by both conventional and Islamic banks in Malaysia were highly similar. The overall efficiency of banks in Malaysia was found to be below 50 percent of optimum efficiency, showing that banks operating in Malaysia were still slacking in utilizing its resources, in terms of deposits and capital, efficiently to produce similar service at a lower cost (Hassan et al., 2009). This could be caused by the aspiration of these banks to provide services with better quality for their customers, leading these banks to incur higher costs (Kraft \& Tirtiroğlu, 1998). Hence, the plan of bank expansion through the setting of new branches should be reconsidered as the cost of setting up new branches would lead to an over-utilisation of capital (Saaid et al., 2003). With respect to the determinants being examined, it could be seen that there was a significantly positive relationship between bank size and conventional bank efficiency while there was no significant relationship found between bank size and Islamic bank efficiency. Evidences from both conventional and Islamic models had also found a significantly negative relationship between operational cost and efficiency. However, there was no significant relationship found between credit risk and Islamic bank efficiency. For the model of conventional banks, it was found that there was a significantly negative relationship between credit risk and efficiency. Hence, it implies that for conventional banks, efficiency would increase with the increment of bank size and decrement of operational cost and credit risk while for Islamic banks; efficiency would increase with the decrement of operational cost. These finding further showed that both types of banks should put more focus towards the utilisation of their operational cost rather than focusing on size or risk. Larger conventional banks should appropriately take advantage of its size, aligning with the theory of Conventional Economic Efficiency in order to obtain optimal efficiency and further gain clients' confidence. For the case of Islamic banks, regardless of the size and risk, management should put more focus in decreasing its cost of operation.

One limitation found from this study was on the availability of data. A comprehensive financial data on Islamic banks could only be retrieved from the year 2008 onwards as Islamic banking in Malaysia is considered to still be relatively new. Hence, with the study heavily relied on financial data from annual reports, this case of data unavailability was indeed an obvious hurdle. The confidentiality of data was also a setback to this study. The calculation of profit efficiency score estimation using Stochastic Frontier Analysis was restricted from being utilized in the study due to its confidentiality issue, as some of the financial data items were unavailable due to this issue. Hence, this study had made full reference on ratios that utilises data that are publicly available.

Unlike past literature, this study has put emphasize on Conventional and Islamic banks operating in Malaysia, 
with an aim to make comparison between the different types of banks. This is because Islamic banks are making significant development over the years. Using financial data from 2008 until 2011, this study had provided the latest outcome of these banks, hence provided more recent efficiency estimates that could be reviewed by both regulators and management of these banks.

For future researches, the methodology of Stochastic Frontier Analysis could be compared with other parametric and non-parametric measures of performance and efficiency such as Data Envelopment Analysis and Malmquist Index. Other than that, as the regression model built in the study did not show complete variation of efficiency being explained by the three selected determinants, there could be other significant factors that would contribute to the changes of performance and efficiency in financial institutions. Therefore, researchers of future studies could also consider other factors that may affect the changes in performance and efficiency.

\section{Acknowledgements}

We would like to thank Accounting Research Institute and Ministry of Higher Education for the research grant provided in conducting this research.

\section{References}

Ahmad, N. H., \& Ahmad, S. N. (2004). Key factors influencing credit risk of Islamic bank: A Malaysian case. The Journal of Muamalat and Islamic Finance Research, 1-10.

Altunbas, Y., Carbo, S., Gardener, E. P. M., \& Molyneux, P. (2007). Examining the relationships between capital, risk and efficiency in European banking. European Financial Management, 13(1), 49-70. http://dx.doi.org/10.1111\%2Fj.1468-036X.2006.00285.x

Alwyni, F. A. (2011, July). Indonesia - Malaysia: Cross - border linkages through Islamic finance. Paper presented at the Joint High Level Conference in Islamic Finance, Indonesia.

Ariff, M., \& Can, L. (2008). Cost and profit efficiency of Chinese banks: A non-parametric analysis. China Economic Review, 19(2), 260-273. http://dx.doi.org/10.1016\%2Fj.chieco.2007.04.001

Barajas, A., Steiner, R., \& Salazar, N. (1999). Interest spread in banking in Colombia, 1974-96. IMF Staff Papers, $46(2)$.

Barr, R. S., Seiford, L. M., \& Siems, T. F. (1994). Forecasting bank failure: A non-parametric frontier estimation approach. Recherches Economiques de Louvain, 60, 417-429.

Bashir, A. H. M. (2001). Assessing the performance of Islamic banks: some evidence from the Middle East. Paper presented in American Economic Association Annual Meeting, Louisiana.

Bashir, A. M. (1999). Risk and profitability measures in Islamic banks: The case of two Sudanese banks. Islamic Economic Studies, 6(2), 1-24.

Baten, A., \& Kamil, A. A. (2010). A stochastic frontier model on measuring online bank deposits efficiency. African Journal of Business Management, 4(12), 2438-2449.

Berger, A. N., \& Bouwman, C. H. S. (2013). How does capital affect bank performance during financial crises? Journal of Financial Economics, 109(1), 146-176. http://dx.doi.org/10.1016/j.jfineco.2013.02.008

Berger, A. N., \& Humphrey, D. B. (1997). Efficiency of financial institutions: International survey and directions for future research. European Journal of Operational Research, 98(2), 175-212. http://dx.doi.org/10.1016/S0377-2217(96)00342-6

Berger, A. N., Hunter, W. C., \& Timme, S. G. (1993). The efficiency of financial institutions: A review and preview of research past, present, and future. Journal of Banking and Finance, 17(2-3), 221-249. http://dx.doi.org/10.1016/0378-4266(93)90030-H

Board of Governors of the Federal Reserve System. (2005). The Federal Reserve in the U.S. Payments System. Retrieved November 21, 2012, from http://www.federalreserve.gov/pf/pdf/pf_7.pdf

Bos, J. W. B., \& Kool, C. J. M. (2006). Bank efficiency: The role of bank strategy and local market conditions. Journal of Banking and Finance, 30(7), 1953-1974. http://dx.doi.org/10.1016/j.jbankfin.2005.07.008

Cadet, R. L. (2008). Cost and profit efficiency of banks in Haiti: Do domestic banks perform better than foreign banks? Working Paper, Université de Rennes.

Cebenoyan, A. S., \& Strahan, P. E. (2004). Risk management, capital structure and lending at banks. Journal of Banking and Finance, 28(1), 19-43. http://dx.doi.org/10.1016/S0378-4266(02)00391-6 
Central Bank of Malaysia. (2001). Financial Sector Masterplan (2001-2010). Kuala Lumpur: Central Bank of Malaysia.

Central Bank of Malaysia. (2012). List of Licensed Banking Institutions in Malaysia: Commercial Banks. Retrieved November 14, 2012 from http://www.bnm.gov.my/index.php?ch=li\&cat=banking\&type $=\mathrm{CB} \&$ fund $=0 \& \mathrm{cu}=0$

Central Bank of Malaysia. (2012). List of Licensed Banking Institutions in Malaysia: Islamic Banks. Retrieved November 14, 2012, from http://www.bnm.gov.my/index.php?ch=li\&cat=islamic\&type=IB\&fund $=0 \& c u=0$

Chen, C. (2009). Bank Efficiency in Sub-Saharan African Middle-Income Countries. Working Paper, International Monetary Fund.

CIMB Group. (2011). About us - History. Retrieved November 12, 2011, from http://www.cimb.com/index.php?ch=g2_au\&pg=g2_au_content\&ac=14\&tpt=cimb_group

Das, A., \& Ghosh, S. (2009). Risk, capital and operating efficiency: Evidence from Indian public sector banks. Indian Journal of Economics and Business, 13(2004), 147-164.

Delis, M. D., \& Papanikolaou, N. I. (2009). Determinants of bank efficiency: Evidence from a semi-parametric methodology. Managerial Finance, 35(3), 260-275. http://dx.doi.org/10.1108/03074350910931771

Demirgüç-Kunt, A., Laeven, L., \& Levine, R. (2004). Regulations, market structure, institutions, and the cost of financial intermediation. Journal of Money, Credit, and Banking, 36(3b), 593-622. http://dx.doi.org/10.1353/mcb.2004.0045

El Moussawi, C., \& Obeid, H. (2011). Evaluating the productive efficiency of Islamic banking in GCC: A non-parametric approach. International Management Review, 7(1), 10-21.

Fiordelisi, F., Marques-Ibanez, D., \& Molyneux, P. (2011). Efficiency and risk in European banking. Journal of Banking and Finance, 35(5), 1315-1326. http://dx.doi.org/10.1016\%2Fj.jbankfin.2010.10.005

Fuentes, R., \& Vergara, M. (2003, May). Explaining Bank Efficiency: Bank Size or Ownership Structure? Paper presented at the Proceedings of the VIII Meeting of the Research Network of Central Banks of the Americas, Venezuela.

Girardone, C., Molyneux, P., \& Gardener, E. P. M. (2004). Analysing the determinants of bank efficiency: The case of Italian banks. Applied Economics, 36(3), 215-227. http://dx.doi.org/10.1080/0003684042000175334

Gjirja, M. (2003). Assessing the efficiency effects of bank mergers in Sweden: A panel-based Stochastic Frontier Analysis. Working Paper, University of Göteborg.

Hassan, M. K. (2005, December). The cost, profit and X-efficiency of Islamic banks. Paper Presented at the 12th ERF Annual Conference, Egypt.

Hassan, T., Mohamad, S., \& Bader, M. K. I. (2009). Efficiency of conventional versus Islamic banks: evidence from the Middle East. International Journal of Islamic and Middle Eastern Finance and Management, 2(1), 46-65. http://dx.doi.org/10.1108/17538390910946267

Hughes, J. P., \& Mester, L. J. (2009). Efficiency in banking: Theory, practice and evidence. In Berger, A. N., Molyneux, P., \& Wilson, J. O. S. (Eds.), Oxford Handbook of Banking. London: Oxford University Press.

Hughes, J. P., \& Mester, L. J. (2011). Who said large banks don't experience scale economies?: Evidence from a risk-return-driven cost function. Working Paper, Federal Reserve Bank of Philadelphia. http://dx.doi.org/10.2139/ssrn.1904527

Ismail, R., \& Zainal Abidin, S. (2009). Efficiency level of Malay-owned firms and the recurrent determinant factors in the Malaysian service sector. International Bulletin of Business Administration, 6, 6-18.

Kamaruddin, B. H., Safa, M. S., \& Mohd, R. (2008). Assessing production efficiency of Islamic banks and conventional bank Islamic windows in Malaysia. International Journal of Business and Management Research, 1(1), 31-48.

Kraft, E., \& Tirtiroğlu, D. (1998). Bank Efficiency in Croatia: A Stochastic-Frontier Analysis. Journal of Comparative Economics, 26(2), 282-300. http://dx.doi.org/10.1006/jcec.1998.1517

Kwan, S., \& Eisenbeis, R. A. (1997). Bank risk, capitalization, and operating efficiency. Journal of Financial Services Research, 12(2/3), 117-131. http://dx.doi.org/10.1023/A:1007970618648

Lang, G., \& Welzel, P. (1996). Efficiency and technical progress in banking: Empirical results for a panel of 
German cooperative banks. Journal of Banking \& Finance, 20(6), 1003-1023. http://dx.doi.org/10.1016/0378-4266(95)00040-2

Lu, K., Yang, M., Hsiao, F., \& Lin, H. (2007). Measuring the operating efficiency of domestic banks with DEA. International Journal of Business Performance Management, 9(1), 22-42. http://dx.doi.org/10.1504/IJBPM.2007.011494

Mat-Nor, F., Mohd Said, R., \& Hisham, M. (2006). Financial performance and efficiency changes of Malaysian banking institutions in mergers and acquisitions. Bank and Bank Systems, 1(1), 102-109.

Milbourn, T. T., Boot, A. W. A., \& Thakor, A. V. (1999). Megamergers and expanded scope: Theories of bank size and activity diversity. Journal of Banking and Finance, 23(2-4), 195-214. http://dx.doi.org/10.1016/S0378-4266(98)00079-X

Miller, S. M., \& Noulas, A. G. (1996). The technical efficiency of large bank production. Journal of Banking and Finance, 20(3), 495-509. http://dx.doi.org/10.1016/0378-4266(95)00017-8

Mohamad, S., Hassan, T., \& Bader, M. K. I. (2008). Efficiency of conventional versus Islamic banks: International evidence using the Stochastic Frontier Approach (SFA). Journal of Islamic Economics, Banking and Finance, 4, 107-130.

Ndu, C. C., \& Wetmore, J. L. (2005). Is the Survival of Small Banks Threatened? A Comparative Performance Evaluation of U.S. Commercial Banks 1997-2002. Journal of International Finance and Economics, 2, 98-117.

Ng, J., \& Rusticus, T. O. (2012, December). Banks' survival during the financial crisis: The role of regulatory reporting quality. Paper to be presented at the World Finance and Banking Symposium, Shanghai. http://dx.doi.org/10.2139/ssrn.1892481

Nigmonov, A. (2010). Bank performance and efficiency in Uzbekistan. Eurasian Journal of Business and Economics, 3(5), 1-25.

Pramuka, B. A. (2011). Assessing profit efficiency of Islamic banks in Indonesia: An intermediation approach. Journal of Economics, Business and Accountancy Ventura, 14(1), 79-88.

QFinance. (2010). Understanding Economic Efficiency theory. Retrieved November 21, 2012 from http://www.qfinance.com/contentFiles/QF01/g4fqn4jz/12/0/understanding-economic-efficiency-theory.pdf

Rossi, S. P. S., Schwaiger, M., \& Winkler, G. (2005). Managerial behavior and cost/profit efficiency in the banking sectors of Central and Eastern European countries. Working Paper, Oesterreichische Nationalbank. http://dx.doi.org/10.2139/ssrn.676365

Saaid, A. E., Rosly, S. A., Ibrahim, M. H., \& Abdullah, N. (2003). The X-efficiency of the Sudanese Islamic banks. IIUM Journal of Economics and Management, 11(2), 1-20.

Said, A. (2012). Comparing the change in efficiency of the Western and Islamic banking systems. Journal of Money, Investment and Banking, 23(2012), 149-180.

Schwarcz, S. L. (2008). Systemic Risk. The Georgetown Law Journal, 97(193), 193-249.

Siddiqui, M. A., \& Shoaib, A. (2011). Measuring performance through capital structure: Evidence from banking sector of Pakistan. African Journal of Business Management, 5(5), 1871-1879.

Srairi, S. A. (2010). Cost and profit efficiency of conventional and Islamic banks in GCC countries. Journal of Productivity Analysis, 34(1), 45-62. http://dx.doi.org/10.1007/s11123-009-0161-7

Sufian, F., Abdul Majid, M., \& Haron, R. (2008). Efficiency and bank merger in Singapore: A joint estimation of non-parametric, parametric and financial ratios analysis. MPRA Paper Series, University Library of Munich.

Thangavelu, S. M., \& Findlay, C. (2010, February). Bank efficiency, regulation and response to crisis of financial institutions in selected Asian countries. Paper presented at the ERIA Workshop Program "Linkages between Real and Financial Aspects of Economic Integration in East Asia”, Singapore.

Wild, J. J., Shaw, K. W., \& Chiappetta, B. (2009). Principles of accounting (19th ed.). Singapore: McGraw-Hill.

Yudistira, D. (2004). Efficiency in Islamic banking: An empirical analysis of eighteen banks. Islamic Economic Studies, 12(1), 1-19. 


\section{Copyrights}

Copyright for this article is retained by the author(s), with first publication rights granted to the journal.

This is an open-access article distributed under the terms and conditions of the Creative Commons Attribution license (http://creativecommons.org/licenses/by/3.0/). 